Abstract IDDF2021-ABS-0084 Table 1 Clinical profile of the patients who had ascites after LDLT

\begin{tabular}{|c|c|c|c|c|c|c|c|}
\hline & Case 1 & Case 2 & Case 3 & Case 4 & Case 5 & Case 6 & Case 7 \\
\hline Age (years) & 62 & 23 & 65 & 50 & 54 & 22 & 46years \\
\hline Sex & Female & Female & Male & Male & Female & Female & Male \\
\hline $\begin{array}{l}\text { Indication for } \\
\text { transplant } \\
\text { Pre transplant } \\
\text { factors }\end{array}$ & NASH & $\begin{array}{l}\text { Chronic Buddi- } \\
\text { Chiari Syndrome }\end{array}$ & AUD-related & AUD-related & Chronic Hepatitis B & Wilson's disease & AUD-related \\
\hline Ascites & Yes & Yes & Yes & Yes & Yes & Yes & Yes \\
\hline Refractory ascites & Yes & Yes & No & Yes & Yes & No & Yes \\
\hline HRS & Yes & No & Yes & Yes & Yes & Yes & No \\
\hline SBP & No & No & No & No & Yes & No & No \\
\hline $\begin{array}{l}\text { Hepatic } \\
\text { encephalopathy }\end{array}$ & No & No & Yes & Yes & No & No & Yes \\
\hline Shunt surgery & No & Yes & No & No & Yes & No & No \\
\hline CIT & $105 \mathrm{~min}$ & $95 \mathrm{~min}$ & $118 \min$ & $120 \mathrm{~min}$ & $85 \mathrm{~min}$ & $65 \mathrm{~min}$ & 98 \\
\hline Early resurgery & $\begin{array}{l}\text { MHV thrombosis - } \\
\text { Thrombectomy on POD1 }\end{array}$ & $\begin{array}{l}\text { Yes-Trans gastric } \\
\text { bilioma drainage }\end{array}$ & No & No & No & No & No \\
\hline $\begin{array}{l}\text { Time for onset of } \\
\text { ascites }\end{array}$ & 3 months & 2.5 months & 3 months & 3 months & 3 months & 3 months & 3 months \\
\hline USG Doppler & $\begin{array}{l}\text { Normal hepatic blood } \\
\text { flow }\end{array}$ & $\begin{array}{l}\text { Normal hepatic } \\
\text { blood flow }\end{array}$ & $\begin{array}{l}\text { Normal hepatic } \\
\text { blood flow }\end{array}$ & $\begin{array}{l}\text { Normal } \\
\text { hepatic blood } \\
\text { flow }\end{array}$ & Normal hepatic blood flow & Normal hepatic blood flow & $\begin{array}{l}\text { Normal } \\
\text { hepatic blood } \\
\text { flow }\end{array}$ \\
\hline \multicolumn{8}{|l|}{$\begin{array}{l}\text { Ascitic fluid } \\
\text { analysis }\end{array}$} \\
\hline Protein (g/dL) & 3.5 & 4.5 & 3.4 & 3.3 & 3.5 & 2.8 & 5.5 \\
\hline Sugar (mg/dL) & 102 & 92 & 133 & 148 & 427 & 128 & 121 \\
\hline Albumin ( $g / d L)$ & 2.1 & 2.2 & 1.9 & 2.0 & 2.2 & 1.5 & 2.3 \\
\hline $\operatorname{ADA}(\mathrm{u} / \mathrm{dL})$ & 37 & 33 & 6 & 40 & 23 & 5 & 33 \\
\hline $\begin{array}{l}\text { Cell count(cell/ } \\
\text { hpf) }\end{array}$ & 800 & 750 & 100 & 350 & 400 & 200 & 560 \\
\hline Cell type & 95\% lymphocytes & 95\% lymphocytes & 93\% lymphocytes & $\begin{array}{l}95 \% \\
\text { lymphocytes }\end{array}$ & $80 \%$ lymphocytes & 95\% lymphocytes & $\begin{array}{l}98 \% \\
\text { lymphocytes }\end{array}$ \\
\hline Cultures & Negative & Negative & Negative & Negative & Negative & & \\
\hline Others & - & - & - & $\begin{array}{l}\text { MTB PCR } \\
\text { Positive }\end{array}$ & $\begin{array}{l}\text { GeneXpert MTB positive. Triglyceries } \\
\text { in AF(ascitic fluid-518 mg/dL) }\end{array}$ & $\begin{array}{l}\text { Renal Biopsy showed chronic } \\
\text { tubulointerstitial nephritis }\end{array}$ & $\begin{array}{l}\text { Gene } X \text { pert } \\
\text { MTB positive }\end{array}$ \\
\hline 2D ECHO & Normal & Normal & Normal & Normal & Normal & Normal & Normal \\
\hline HVPG & Not done & $9 \mathrm{mmHg}$ & $10 \mathrm{mmHg}$ & Not done & Not done & Not done & Not done \\
\hline $\begin{array}{l}\text { Liver biopsy } \\
\text { Others }\end{array}$ & Not done & Not done & $\begin{array}{l}\text { Normal } \\
\text { Renal Biopsy- Ig } \\
\text { A nephropathy }\end{array}$ & Not done & Not done & Normal & Not done \\
\hline Diagnosis & Tubercular ascites & Tubercular ascites & $\lg A$ nephropathy & $\begin{array}{l}\text { Tubercular } \\
\text { ascites }\end{array}$ & Tubercular ascites & $\begin{array}{l}\text { Tacrollmus Induced proteinuria } \\
\text { and CKD }\end{array}$ & $\begin{array}{l}\text { Tubercular } \\
\text { ascites }\end{array}$ \\
\hline
\end{tabular}

\section{IDDF2021-ABS-0088 UTILITY OF PRE AND POST TREATMENT ALPHA-FETOPROTEIN IN THE PROGNOSIS OF HEPATOCELLULAR CARCINOMA TREATED WITH ULTRASOUND-GUIDED PERCUTANEOUS RADIOFREQUENCY ABLATION}

Virgilio Jr Lo*, Rommel Romano, Stephen Wong. University Of Santo Tomas, Philippines

10.1136/gutjnl-2021-IDDF.85

Background Post-treatment alpha-fetoprotein (AFP) response has been reported to be associated with prognosis of hepatocellular carcinoma (HCC). We aimed to determine whether pre-and post-treatment AFP are associated with survival for HCC patients undergoing radiofrequency ablation (RFA).

Methods RFA was performed on 166 index HCC patients from 2007 to 2018. Post-treatment AFP was monitored at 1-
,3- and 6-months and percentage AFP responses were computed from pre-treatment AFP. Overall Survival (OS) was estimated using Kaplan-Meier; log-rank and Cox regression analysis of predictors were analyzed.

Results Pre-treatment AFP levels $\geq 10 \mathrm{ng} / \mathrm{ml}, \geq 100 \mathrm{ng} / \mathrm{ml}$ and $\geq 1000 \mathrm{ng} / \mathrm{ml}$ were observed in $55.1 \%$ (92/166), 31.1\%(52/166) and 9.6\%(16/166), respectively. Patients with pre-treatment $\mathrm{AFP} \geq 10 \mathrm{ng} / \mathrm{ml}$ had poorer OS compared to $\mathrm{AFP}<10 \mathrm{ng} / \mathrm{ml}$ (1,3- and 5-year: $77.3 \%, 50.7 \%, 23.3 \%$ vs 93.1\%,70.1\%,42.2\%; $\mathrm{p}=0.003)$. In those with normal post-treatment AFP, AFP response $\geq 50 \%$ at 6 months was a predictor of OS (1-,3- and 5-year: 96.4\%,84.4\%,62.8\%; $\mathrm{p}=0.014)$. In those with high post-treatment AFP, AFP response $\geq 50 \%$ at 1 month $(p=0.009)$ and 3 months $(p=0.002)$ were predictors of OS. Furthermore, normal AFP at any time during 1-,3- or 6months post treatment with RFA were associated with better OS $(p<0.001)$. When pre- and post-treatment AFP were 


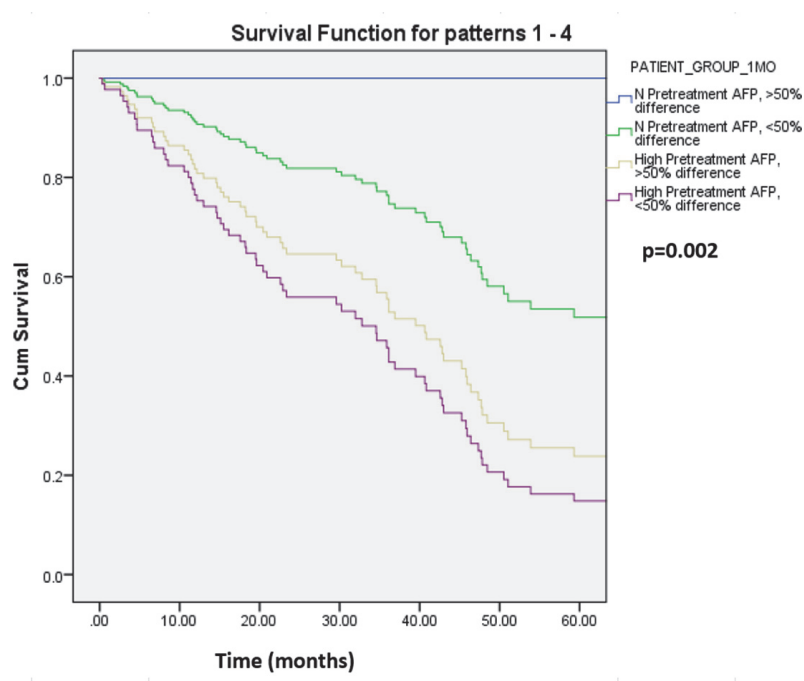

Abstract IDDF2021-ABS-0088 Figure 1 Kaplan-Meier curve for overall survival of HCC patients based on pre-treatment AFP and posttreatment AFP response $\geq 50 \%$ at 1 -month after RFA

analyzed, pre-treatment $\mathrm{AFP}<10 \mathrm{ng} / \mathrm{ml}$ and post-treatment AFP response $\geq 50 \%$ at 1 month yielded the best estimated 5 -year survival $(p=0.002)$ - (IDDF2021-ABS-0088 Figure 1. KaplanMeier Curve for Overall Survival of HCC Patients based on Pre-treatment AFP and Post-treatment AFP response $\geq 50 \%$ at 1 month after RFA).

Conclusions Pre-treatment $\mathrm{AFP}<10 \mathrm{ng} / \mathrm{ml}$, 6-months post-treatment AFP response $\geq 50 \%$ with normal AFP and 1- and 3months post-treatment AFP response $\geq 50 \%$ with high AFP were predictors of better OS. AFP $<10 \mathrm{ng} / \mathrm{mL}$ at any time during 1-,3- or 6-months after RFA was an important predictor of better prognosis. The best prognosticator for OS was a patient with pre-treatment $\mathrm{AFP}<10 \mathrm{ng} / \mathrm{ml}$ and post-treatment AFP response $\geq 50 \%$ at 1 month.

\section{IDDF2021-ABS-0089 PRIMARY NORFLOXACIN PROPHYLAXIS REDUCES THE INCIDENCE OF INFECTIONS IN SEVERE ALCOHOLIC HEPATITIS-A DOUBLE-BLIND, RANDOMIZED CONTROLLED STUDY}

Anand Kulkarni*, Sowmya Iyengar, Syeda Fatima, Mithun Sharma, PN Rao, D Nageshwar Reddy. Asian Institute of Gastroenterology, India

\subsection{6/gutjnl-2021-IDDF.86}

Background Steroid therapy is the standard of care for severe alcoholic hepatitis (sAH) at most centres. However, steroids are associated with an increased risk of infections. Therefore, we aimed to compare the outcomes of patients receiving concomitant norfloxacin (NFX) with steroids in patients with sAH.

Methods In this double-blind, randomized study, acute-onchronic liver failure (ACLF) patients without sepsis, hepatic encephalopathy, or SBP were assigned to receive oral NFX $400 \mathrm{mg}$ or matched placebo (PBO) once daily for 30 days along with standard medical therapy. 143 ACLF patients were included (CTRI/2019/10/021548). On subgroup analysis, 20 in the NFX group and 13 patients in the PBO group received concomitant steroid therapy for sAH. The primary objective was to assess the incidence of infections at days 30, 90, and



Abstract IDDF2021-ABS-0089 Figure 1

the secondary was to evaluate the transplant-free survival (TFS) at days 30, 90.

Results Baseline characteristics were similar in both the groups (MELD-NFX-27.8 \pm 3.79 vs. PBO-29.62 $\pm 4.66 ; \mathrm{P}=0.229$ ). The incidence of infection was lower with NFX (10\%) than PBO $(38.5 \%)$ at day $30(\mathrm{P}=0.066)$. The incidence of infection at day 90 was lower with NFX (30\%) than PBO (69.2\%) $(\mathrm{P}=0.027)$ (IDDF2021-ABS-0089 Figure 1. Kaplan Meier analysis of infection incidence at days 30,60 and 90). TFS was similar in both groups at day 30 (NFX-85\% vs. PBO-77\%; Log-Rank test: $\mathrm{P}=0.524)$. However, TFS at day 90 was better with NFX (85\%) than placebo $(53.8 \%)$ (Log-Rank test: $\mathrm{P}=0.059)$. The most common source of infection was the urinary tract (NFX - 3 vs. Placebo-4). E. coli was the commonly isolated organism in both groups. Candida albicans were isolated in two patients in NFX group, while none in the PBO group developed fungal infection. Sepsis was the common cause of mortality (NFX-2; PBO-4). Further, one patient in NFX group succumbed to post-TIPS liver failure (for variceal bleed). There were no drug-related adverse events in this subgroup of patients.

Conclusions Primary norfloxacin prophylaxis is safe and effective in reducing infections in patients with sAH receiving steroid therapy.

IDDF2021-ABS-0092
A DIAGNOSTIC TEST META-ANALYSIS
EVALUATING THE PERFORMANCE
OF IMAGING-BASED AND BLOOD
BIOMARKER-BASED ASSESSMENT
TOOLS FOR FIBROSIS AFTER LIVER
TRANSPLANTATION

${ }^{1}$ Cheng Han Ng* ${ }^{*}$ Xiong Chang Lim, ${ }^{1}$ Darren Jun Hao Tan, ${ }^{1} J i e$ Ning Yong, ${ }^{1}$ Nicholas Syn, ${ }^{1}$ Gwyneth Shook Ting Soon, ${ }^{1}$ Eunice Xiang Xuan Tan, 'Yock Young Dan, ${ }^{1}$ Mark Dinesh Muthiah, ${ }^{2}$ Mohammad Shadab Siddiqui. 'Yong Loo Lin School of Medicine, Singapore; ${ }^{2}$ Vierginea Commonwealth University, Virginia, USA

\subsection{6/gutjnl-2021-IDDF.87}

Background Assessing fibrosis after liver transplant (LT) remains a core concern and can suggest the presence of de novo nonalcoholic fatty liver disease or recurrence after 